University of Nebraska - Lincoln

DigitalCommons@University of Nebraska - Lincoln

9-1938

\title{
THE NEBRASKA STATE GEOLOGICAL SURVEY AND THE "VALENTINE PROBLEM"
}

Alvin Leonard Lugn

University of Nebraska-Lincoln

Follow this and additional works at: https://digitalcommons.unl.edu/geosciencefacpub

Part of the Earth Sciences Commons

Lugn, Alvin Leonard, "THE NEBRASKA STATE GEOLOGICAL SURVEY AND THE "VALENTINE PROBLEM"'" (1938). Papers in the Earth and Atmospheric Sciences. 357.

https://digitalcommons.unl.edu/geosciencefacpub/357

This Article is brought to you for free and open access by the Earth and Atmospheric Sciences, Department of at DigitalCommons@University of Nebraska - Lincoln. It has been accepted for inclusion in Papers in the Earth and Atmospheric Sciences by an authorized administrator of DigitalCommons@University of Nebraska - Lincoln. 


\section{THE NEBRASKA STATE GEOLOGICAL SURVEY AND THE "VALENTINE PROBLEM."'}

\section{A. L LUGN. ${ }^{2}$}

The writer is hesitant to enter the discussion of this vexing problem. As a matter of fact, perhaps too much already has been said and published on the subject. However, certain facts should be understood clearly, and it is the purpose of the writer to try to clarify certain matters.

Except in only rare instances, the State Geological Survey has always had complete coöperation from outside geologists representing established institutions like museums, geological surveys, etc., commercial companies, oil geologists, and many other individual geologists. There have been a few exceptions, and certain individuals have come into this state to collect fossils and make geologic observations; and then return from whence they came without making contacts with the local authorities; and prepare manuscripts and publish papers in which proposals have been made to revise portions of the geology of Nebraska, which they were incompetent to do, and which would not have been approved by the Nebraska Geological Survey. It is quite certain that there would have been no "Valentine problem" in our literature at this time if the Nebraska Survey had received the deserved coöperation from certain individuals, who made the mistake of incorrectly applying the term "Valentine" to a horizon not included in its original range. Every difficulty in connection with the present confusion of names could have been surmounted through an exchange of correspondence and the critical checking of manuscripts before publication.

Some confusion is inevitable when the locality, faunal, or stratigraphic use of a name is not clearly defined by its author. The Nebraska State Geological Survey is primarily concerned with the stratigraphic classification of the Tertiary lithologic units in this state. When the stratigraphic relationships are fully understood, the faunas can be properly and correctly related and named, whether the stratigraphic names or others are used. It should be understood that this survey, in deter-

\footnotetext{
${ }^{1}$ Published by direction of the Nebraska State Geologist, Dr. G. E. Condra, Dean and Director of the Conservation and Survey Division, University of Nebraska, Lincoln, Nebraska.

${ }_{2}^{2}$ Geologist, Nebraska State Geological Survey; and Professor of Geology, University of Nebraska.
} 
mining its acceptance of stratigraphic names on the basis of priority, is making every effort to differentiate names which have been applied in a strictly stratigraphic sense from names which, while they may be older, were applied in only a geographic or faunal sense and have only locality significance for the most part, the term "Niobrara River" for example. Therefore this survey is in agreement with Mr. F. Walker Johnson $^{3}$ and Dr. George Gaylord Simpson" that the name "Valentine" is applied properly only when used for the lower unconsolidated sands and gravels in the lower part of the Ogallala. This survey definitely disagrees with the use of the terms "Niobrara River" (in any sense) and "Valentine" for the upper part of the section as applied by Stirton and McGrew in several papers. ${ }^{5}$ We feel that F. Walker Johnson ${ }^{6}$ has done a very fine piece of work and a great service in straightening out the confusion in terminology in the Valentine, Nebraska, area, and that others have only confused a situation which was not very clear to begin with.

This survey cannot agree to the use of the term "Niobrara River" to apply to any part of the section in the Valentine, Nebraska, area because of the possible confusion with the "Niobrara" formation of Cretaceous age in essentially the same area. We feel that this is a serious and valid objection to "Niobrara River" as proposed by Stirton and others. ${ }^{7}$ Cope $^{8}$ called attention to this same objection to "Niobrara" many years ago. Hayden collected "from the sands of the Niobrara

${ }^{3}$ Johnson, F. Walker: The Status of the Name "Valentine" in Tertiary Geology and Paleontology, This Journal, Vol. 31, pp. 467-475, 1936.

${ }^{4}$ Simpson, George Gaylord: Glossary and Correlation Charts of North American Tertiary Mammal-Bearing Formations, Amer. Mus. of Natural Hist., Vol. LXVIII, Article III, p. 113, 1933.

${ }^{5}$ Stirton, R. A.: A Critical Review of the Mint Canyon Mammalian Fauna and Its Correlative Significance, This Journal, Vol. 26, pp. 569-576, 1933.

: A Review of the Tertiary Beavers, Uni. of Calif. Pub., Bull. Dept. Geol. Sci., Vol. 23, No. 13, pp. 391-458, 1935.

: Succession of North American Continental Pliocene Mammalian Faunas, This Journal, Vol. 32 pp. 161-206, 1936.

Stirton, R. A., and McGrew, Paul O.: A Preliminary Notice on the Miocene and Pliocene Mammalian Faunas Near Valentine, Nebraska, This Journal, Vol. 29, pp. 125-132, 1935.

Stirton, R. A., and Teilhard de Chardin, P.: A Correlation of Some Miocene and Pliocene Mammalian Assemblages in North America and Asia with a discussion of the Mio-Pliocene Boundary, Uni. Calif. Pub., Bull. Dept. Geol. Sci., Vol. 23, No. 8, pp. 277-290, 1934.

J Johnson, F. Walker : op. cit.

'Stirton, R. A., and McGrew, Paul: op. cit.

${ }^{8}$ Cope, E. D.: The Mesozoic and Cenozoic Realms of the Interior of North America, American Naturalist, pp. 445-462, 1887. 
River" through Nebraska and west into Wyoming from formations of Pliocene (Ogallala) age to older Miocene, making no differentiations. He even collected Pleistocene fossils also "from the sands of the Niobrara River." Leidy described Hayden's collections later, and there is no evidence in any of his statements that "the sands of the Niobrara River" ever meant anything but a general locality term. This is especially evident when it is noted that Hayden's fossils ranged in age from Miocene to Pleistocene.

Also, this survey considers it proper and expedient in some instances to retain a well established name that has long been in use and is widespread in the literature in preference to some hazy, obscure name, which by some manner might be shown to have had slightly prior usage in some little known publication, or which has not gained wide recognition and use, or has been largely abandoned. For example, it could very well be argued that the term "Devil's Gulch" should be used as a formational name in place of "Valentine," since the "Devil"s Gulch" beds, even including the Burge channel member, are exactly equivalent to the Valentine formation, and the name was applied by Barbour ${ }^{10}$ in 1914. Apparently most of the Devil's Gulch fossils until very recently were collected from the upper part of the exposures, mainly the "Burge" and "cap rock bed" horizons - the Pliocene part of the section, in Devil's Gulch in northeastern Brown County, Nebraska. This accounts for the general classification of the Devil's Gulch beds as of Pliocene age while the Valentine beds have commonly been referred to the Miocene, because the "Valentine fauna" has been collected from lower down, perhaps at least 100 feet lower, in the exposures - the Miocene(?) part of the section, at Valentine, Nebraska. ${ }^{11}$

The Nebraska State Geological Survey has tried to settle on a nomenclature for its Tertiary stratigraphy which will be generally acceptable, and the units of which are mappable. Obviously all of the faunal names cannot be applied as stratigraphic names, and only the names which apply to mappable units can survive as formational or group names, regardless of the original application of any name. This is especially

\footnotetext{
${ }^{9}$ Leidy, Joseph: The Extinct Mammalian Fauna of Dakota and Nebraska, Jour. of the Academy of Natural Sciences of Philadelphia, Vol. VII, Second Series, 1869.

${ }_{10}$ Barbour, E. H.: Mammalian Fossils from Devil's Gulch, Nebr. Geol. Survey (First Series), Vol. IV, Pt. 11, pp. 177-190, 1914.

${ }^{11}$ Scott, Wm. B.: A History of Land Mammals in the Western Hemisphere, pages 97, 107-112, 2nd ed., Macmillan, New York, 1937.
} 
true of the "Valentine," which was used by Barbour and Cook ${ }^{12}$ in 1917, and which has been well described and defined by Johnson. ${ }^{13}$

It is a very satisfactory stratigraphic name for all of the more or less unconsolidated, fine, gray sands, 175 to 225 feet in thickness, which constitute the lowest and oldest formation of the Ogallala group. The Valentine formation occurs under the typical Ogallala "mortar beds." The "cap rock bed," a field term mentioned by Johnson, ${ }^{14}$ is the lowest part of the "mortar beds" division of the Ogallala group. It, the "cap rock bed," is also almost exactly the equivalent of the Krynitzkia fossil seed zone of Elias. ${ }^{15}$ It contains the "upper" of Stirton and McGrew's ${ }^{16}$ three faunas, to which they proposed to apply the name "Valentine" in a redefined sense. The Burge channel member of the Valentine formation occurs at the very top of the Valentine below the Krynitzkia seed zone, and the true "Valentine fauna" comes from lower down in the formation (at about 80 feet above the Valentine-Brule clay contact southeast of Valentine, Nebraska).

The "mortar beds" division of the Ogallala group, which in the main is the only part exposed in the "type locality" (?) near Ogallala, Nebraska, as defined by Elias, ${ }^{17}$ is now to be known as the Ash Hollow formation, 100 to 250 feet thick. It contains the "cap rock bed" of the Krynitzkia coronoformis fossil seed zone, the "fragmental" vertebrate fossil zone (the third and highest faunal zone of Stirton and McGrew, ${ }^{18}$ mistakenly called by them "Valentine") in the lower part of the

\footnotetext{
${ }^{12}$ Barbour, E. H., and Cook, Harold J.: Skull of Aelurodon platyrhinus, sp. nov., Nebr. Geol. Survey (First Series), Vol. VII, Pt. 19, pp. 173-180, April, 1917.

${ }^{13}$ Johnson, F. Walker: op. cit.

${ }_{14}$ Johnson, F. Walker: op. cit. pp. 472-473.

${ }^{15}$ Elias, Maxim K.: Grasses and Other Plants from the Tertiary Rocks of Kansas and Colorado, Bull. of the Uni. of Kans. Geol. Survey, Vol. XXXIII, No. 10, 1932.

: Tertiary Grasses and Other Prairie Vegetation From High Plains of North America, This Journal, Vol. 29, pp. 24-33, 1935.

Chaney, Ralph W., and Elias, Maxim K.: Late Tertiary Floras from the High Plains, Carnegie Inst. of Washington, Pub. No. 476, pp. 1-72, 1936.

${ }^{16}$ Stirton, R. A., and McGrew, Paul: A Preliminary Notice on the Miocene and Pliocene Mammalian Faunas Near Valentine, Nebraska, This Journal, Vol. 29, pp. 125-132, 1935.

${ }^{17}$ Elias, Maxim K.: A personal communication quoted by Stirton, R. A., Succession of North American Continental Pliocene Mammalian Faunas, This Journal, Vol. 32, pp. 177-178, 1936. See also Hesse, Curtis J.: A Vertebrate Fauna from the Type Locality of the Ogallala Formation, Bull. Uni. of Kans., Vol. XXXVI, No. 8, pp. 79-117, 1935.

${ }^{18}$ Stirton, R. A., and McGrew, Paul: op cit.
} 
formation. The remainder of the Ash Hollow formation includes most of the Biorbia fossilia fossil seed zone of Elias. ${ }^{19}$ This part of the formation also contains several other faunal zones; and in the Valentine, Nebraska, area, near Burge, farther east in northeastern Cherry County, northern Brown County, and in Keya Paha County, the lower part of the Biorbia zone contains an abundant vertebrate fauna, which is higher than any mentioned by Stirton and McGrew. ${ }^{20}$ The association of Biorbia fossilia with this higher fauna was discovered by Morris Skinner and the writer in 1935. Correlative faunas to the two in the lower part of the Ash Hollow formation in the Valentine, Nebraska, area and other still higher faunas are known from other areas in southern and southwestern Nebraska.

The third formation of the Ogallala group is now known as the Sidney gravel formation from occurrences at Sidney, Nebraska. It ranges in thickness from 15 to 50 feet; and it is widespread in southwestern Nebraska, northeastern Colorado, and in parts of western Kansas. It is the upper part of the Biorbia fossil seed zone.

A fourth and uppermost formation of the Ogallala group is to be known as the Kimball formation from its typical occurrence at the highest remnant levels of the High Plains in Kimball County, Nebraska. The thickness of the Kimball formation ranges from 30 to 40 feet when present in its full development; and it consists of silt, clay, fine sand more or less cemented with caliche, with one or two algal limestone beds at the very top. It is pinkish to reddish in color. It contains the fossil seeds of the genera Echinochloa, Panicum, and also Biorbia. ${ }^{21}$ The most striking feature of this formation is the occurrence at the very top of an algal limestone (Chlorellopsis bradleyi Elias)."2 The formation is also widespread in its occurrence.

It should be noted at this point that it now seems evident that the typical "Snake Creek" formation, or at least the so called "upper Snake Creek," is definitely correlative with some part of the upper Ogallala group. Unfortunately "Snake Creek" has been incorrectly applied to beds, mainly channel fills, as late as Pleistocene, and also to other beds as old as

${ }^{19}$ Elias, Maxim K.: same citations as under note 14 .

${ }^{20}$ Stirton, R. A. and McGrew, Paul: op. cit.

${ }^{21}$ Elias, Maxim K.: op. cit.

${ }^{22}$ Elias, Maxim K.: The Geology of Wallace County, Kansas, Bull. Kans. Geol. Survey, No. 18, pp. 136-141, 1931. 
Miocene. Much of the Miocene "Snake Creek" or perhaps the so called "lower Snake Creek" seems to be in part not Snake Creek at all but simply Sheep Creek beds in place and in proper stratigraphic sequence. Also, many of the Miocene and "Sheep Creek" vertebrate fossils which have been collected from "Snake Creek" channel deposits have come from very large blocks of Sheep Creek formation, which were broken away from the banks of the Snake Creek streams. These large blocks of rock have dimensions of ten to 20 or more feet and were never broken up or disintegrated by the Snake Creek rivers. They simply lie buried in the younger silt and sand, the true Snake Creek sediment.

The old Ogallala formation, as indicated in the above discussion, is now to be redefined as a group consisting of four definite and mappable formations. The formational names: Valentine, Ash Hollow, Sidney, and Kimball were not the choice of the present writer alone, nor of any one individual. These names were agreed upon first in conference early in March 1936 in the State Geologist's office at Lincoln, Nebraska, by the following: Dr. G. E. Condra, State Geologist of Nebraska; Dr. R. C. Moore, State Geologist of Kansas; Mr. Maxim K. Elias, Kansas State Geological Survey, and the writer. Agreement on Ogallala nomenclature also had been reached with Mr. C. Bertrand Schultz, Assistant Director (in charge), Nebraska State Museum. The Ogallala formations now have been mapped areally in detail by the Nebraska State Geological Survey; and a bulletin will be published soon which will contain these maps and a general and somewhat detailed survey of the stratigraphy of all of the Tertiary system in Nebraska. The acceptable stratigraphic nomenclature will be described. All names used have now been approved by the United States Geological Survey.

A skeleton table of the Tertiary stratigraphic divisions now acceptable in Nebraska and Kansas, and also in adjoining regions of the Great Plains, is included below. No extended discussion or elaborate citation of references can be included here. The Tertiary of this region is divisible into four natural lithologic groups, each of which represents a separate and distinct cycle of sedimentation. The White River, Arikaree, and Ogallala are familiar terms. The White River group remains unchanged. The Arikaree group has been redefined to include the Gering formation as the basal channel development at the beginning of the Arikaree cycle of sedimentation. This redefinition of the Arikaree has already been announced

Am. Jour. Sc.-Fifth Series-Vol. XXXVI, No. 213, September, 1938. 15 
by Schultz. ${ }^{23}$ The Ogallala is redefined as noted above. The Heming ford group is a new division suggested by C. Bertrand Schultz, Assistant Director, Nebraska State Museum, and concurred in by this survey. This is the first publication of the new term. The Heming ford group includes the Marsland and Sheep Creek formations. The Marsland formation is a recent term given by Schultz. ${ }^{24}$ The basis for the use of the term Marsland and the redefinition of the Arikaree has been given fully by Schultz.

It seems appropriate to add here that the Harrison formation is to be understood in the sense in which it was originally defined by Hatcher. ${ }^{25}$ The Marsland formation, the buff to reddish-brown beds which overlie the Arikaree group, were never included in the Harrison formation of Hatcher. Neither was the Marsland a part of Scott's "Nebraska Beds" as Hatcher thought, nor was it ever included in Darton's Arikaree. ${ }^{26}$ Therefore these buff to reddish-brown beds never have had a proper name until the term Marsland was proposed recently. The application of the name "upper Harrison" to these beds by Peterson ${ }^{2 \tau}$ and many others in more recent years has been unfortunate, because these beds (Marsland) have no very close stratigraphic or faunal relation to the true Harrison (in the Hatcher sense), and they are separated from the underlying Harrison formation by the most significant and important structural and erosional unconformity in western Nebraska.

It is hoped that these notes, including the table of Nebraska Tertiary stratigraphic divisions, will be helpful to all; and that the explanations pertaining to the "Valentine problem" may lead to the realization "that some agreement must be reached in this question of names" and the consummation of this end. It is hoped that this discussion and the companion papers in this number of this Journal will definitely correct the recent mis-use of the term Valentine.

\footnotetext{
${ }^{23}$ Schultz, C. Bertrand: The Miocene of Western Nebraska, This Journal, Vol. 35, pp. 441-444, 1938.

${ }^{24}-$ Schultz, C. Bertrand: op. cit.

${ }^{25}$ Hatcher, J. B.: Proc. Am. Phil. Soc., Vol. 41, No. 169, pp. 115-119, 1902. See also Schultz: op. cit.

${ }^{26}$ Darton, N. H.: Geology and Water Resources of Nebraska West of the One Hundred and Third Meridian, U. S. Geol. Survey, Prof. P. 17, p. 17, 1903. See also other papers by Darton, and Schultz: op. cit.

${ }^{27}$ Peterson, O. A.: Annals Carn. Mus., Vol. 4, pp. 21-24, 1906. See also, Schultz: op. cit.
} 


\section{Tertiary Formations of Nebraska}

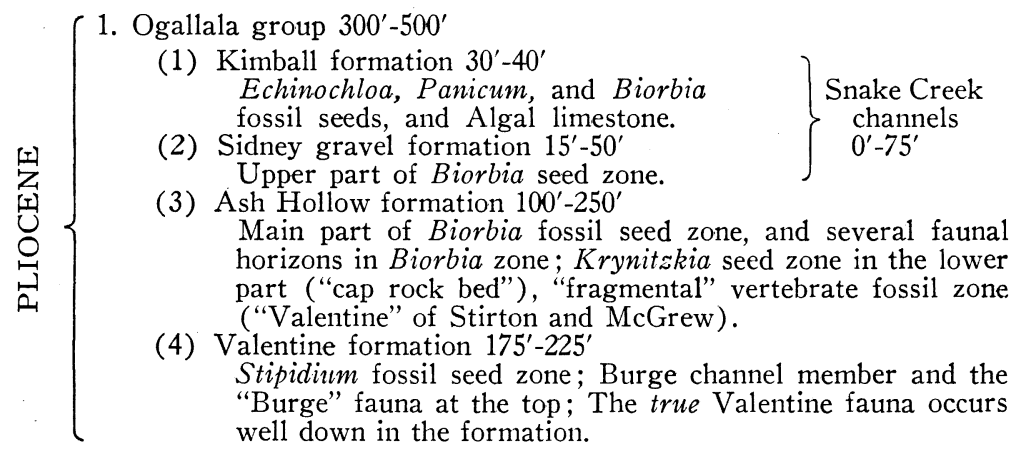
UNCONFORMITY

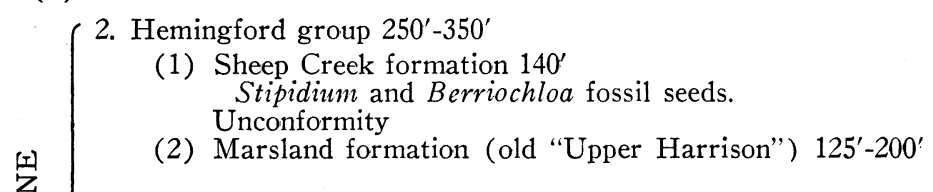

\section{UNCONFORMITY}

Note: Horizon of the folding of the Agate Anticline and many other structures.

3. Arikaree group $700^{\prime}-800^{\prime}$

(1) Harrison formation $200^{\prime}$

Daemonelix beds at the top.

(2) Monroe Creek formation $375^{\prime}$

(3) Gering formation $100^{\prime}-200^{\prime}$

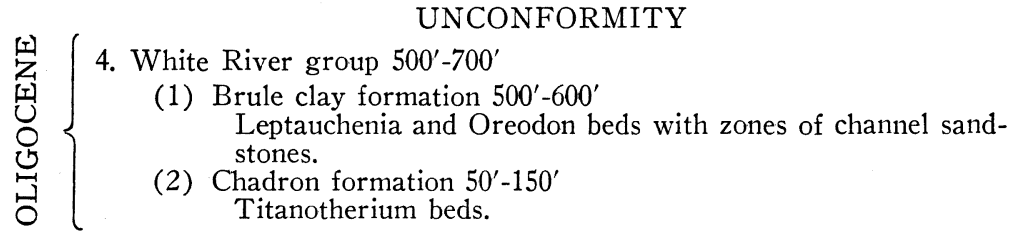

\section{UNCONFORMITY}

Mainly Cretaceous shale formations: Pierre, etc.

Note: Celtis seeds occur throughout all of the Tertiary formations noted above. Celtis hatcheri has been described as from the White River group; most of the Celtis stones from higher formations are generally referred to the species willistoni. The genus Stipidium, perhaps several species, occurs also in the higher formations of the Ogallala group associated with the "index" fossil seeds of these zones. The Miocene-Pliocene contact is still undecided upon as indicated above.

\footnotetext{
Nebraska State Geological Survey,

Lincoln, Nebraska.
} 